\title{
Changing Cities and Changing Memories: The Case of Taksim Square, Istanbul
}

\author{
D. Erbey
}

\begin{abstract}
Memory of places is an important component of tangible and intangible heritage, but urban dynamics mainly force cities to change and urban conservation studies and rarely implement and consider the individual and society's memories about places. During a series of expert meetings, held in various parts of the world and at UNESCO Headquarters from 2005 to 2010, a contemporary approach on the continuity of historic areas, the historic urban landscape (HUL) was developed by adoption of the last UNESCO Recommendation related to heritage preservation. The HUL approach takes a holistic and relational perspective with social elements, showing that the heritage of a physical space needs to be preserved in the same way as the physical elements themselves are preserved.

Istanbul is a metropolitan city that is in conflict between rapid change in the economic, social, cultural and also physical fields and continuity of heritage that has accumulated in historical layers. The main issue is the continuity of memories as well as their interactions with spaces and with the integrity they provide. Taksim Square, which has a historical and significant role in the city, is also a target for urban projects that transform the space. Changes in the functions, references, and the physical environment cause deterioration of people's memories.

In this paper, we discuss how Taksim Square has been changed by planning decisions since 1923 but focusing the period after $1980 \mathrm{~s}$ in order to understand the gap between space and memory, we propose "urban memory" as a new indicator for the HUL approach to sustain its part in the heritage it represents.
\end{abstract}

Index Terms-Urban memory, urban conservation, historic urban landscape, heritage.

\section{URBAN MEMORY-URBAN CONSERVATION}

Cities with historical layers are continuously under change produced by urban dynamics, as are other cities. Historical cities, where conservation phenomena are embraced at the social, legal, and administrative levels, can manage the change created by urban pressures properly. However, cities like metropolitan Istanbul that accept change through global influences are forced to lose traces of their history.

Like every individual in society, each city has its own memory, and individuals and societies have a common social memory. This common memory consists of memories that cannot be independent of spatial references.

Particularly, spatial and functional changes in historical city centers affect the urban-related memories of inhabitants and thereby weaken their emotional ties through loss of memories related to spaces.

Culture comprises all relations formed by the preservation, interpretation, acceptance, and transfer of the values assigned

Manuscript received October 10, 2017; revised November 24, 2017.

D. Erbey is with Mimar Sinan Fine Arts University, Turkey (e-mail: dilekerbey@gmail.com). to events over time. Conflicts between different cultures and their relationships have created cultural evolution, and new forms of relationships (values) have emerged as a dialectical consequence of this evolution. The work of Bandarin and Oers, The Historic Urban Landscape; Managing Heritage in An Urban Century, states that conservation deals with the past and the future at the same time and is "a process of mediating between interpretations of different value systems that create social formation, using the mind to balance the different forces" [1]. In this context, it can be mentioned that the act of conservation is a natural part of the process that constitutes a culture of a society.

Historical environments, arranged as related to human scale, have educational and interesting characteristics. They have spaces that affect social relations in a positive manner and help solidify the feeling of unity among individuals. Being in such places makes the individual feel happy. In a world where living conditions, traditions, and construction techniques change rapidly, historical environments are open-air museums that show how the people in the past lived in a place [2]. Historical environments, however, are also of great importance as values by means of environmental use and social equilibrium, strengthening social ties of the inhabitants along with the influence of continuity and human-scale spaces, enabling and maintaining social ties between individuals and their environment.

The Historical Urban Landscape (HUL) approach is a program initiated within the UNESCO Cities Program in 2005 to incorporate the conservation and planning policies required to ensure the preservation and continuity of historic cities in holistic urban development strategies. Obviously, it is no longer sustainable to try to preserve the living historical cities only as protected areas or, in other words, to be identified as geographically classified special areas to cope with the pressures on these cities. In the light of these discussions, the HUL initiative emerged in the conference of World Heritage and Contemporary Architecture-Managing the Historic Urban Landscape [3]. In the present situation, the size and foreseeable growth of the population in cities form an increasing pressure on historic cities, together with the lack of defined policies for the identification and sustainable use of their historical heritage. This pressure makes preserving the historic urban landscape a more difficult task. In addition, the structural stock that is to be evaluated internally with the social life, which exists together with the space within the fabric of historical cities, is being used as a tool for the development of global tourism in a local area. Although the tourism pressure created by the increasing competitiveness of the cities is considered to be an economic means of generating income in the short term, it causes cities to lose their characteristic features in the long run. Many problems, linked to each other and becoming increasingly 
complex, generally affect the cultural-historical significance of the cities in the World Heritage List, from the growing population and global tourism to the construction of high-rise buildings and functional changes in urban centers. Due to the rapid globalization of the economy, the tendency toward urban transformation and newly developed projects in the historical city centers seems to be increasing. These developments are increasingly emerging as threats to the authentic holistic structure of historic cities. For these reasons, there is a greater need for this updated urban protection tool to allow the management of historic cities living with appropriate protective methods.

In recent years, there has been an increase in the number of talks of the World Heritage Committee on the developments that threaten the unique values of historic cities. At the 31st Session held in New Zealand in 2007, 84 conservation reports were prepared by the World Heritage Center in collaboration with advisory boards such as International Council of Monuments and Sites (ICOMOS), International Union for Conservation of Nature (IUCN), and International Centre for the Study of the Preservation and Restoration of Cultural Property (ICCROM). Thirty-three of these reports relate to the threats posed by urban development and transformation projects, which typically involve the influence of new infrastructure investments, new build-up projets, and high-rise buildings on the values that the historic cities have [4].

It is obvious that the traditional point of view and expectations in the development and preservation of historic cities have been changing. Local authorities in both developed and less-developed countries face difficulties in identifying and resolving this issue. There is a need for a new and powerful method that can be used by local authorities and decision makers in a practical and systematic way to address the impact of all stakeholders on the value of the field and all its values.

In 2011, UNESCO, in its Recommendation on Historic Urban Landscape, defines the concept of Historical Urban Landscape (HUL) as follows: a historical urban landscape should be understood as a place where cultural and natural values coexist in the form of historic strata to reveal the relation of an urban settlement with the urban context and geography to which it is bound, rather than the concepts of "historical center" or "community" [3].

Depending on the conservation and planning legislation in Turkey, the implementation tools have been transformed into separate, fragmented, point, or regional implementations that are independent from each other and independent from a holistic approach of strategic planning. Such approaches result in the persistence of urban cultural heritage and the maintenance of conservation policies overshadowed by urban development strategies. The HUL approach emphasizes that urban development strategies can turn into an opportunity for conservation areas. Questioning the HUL approach and its applicability in Turkey will also lead to the revision of priorities placed on historical values in implementing conservation tools. It is also clear that an urban fabric with its history is inseparable with its traditional way of life, and the historical character of space disappears along with spatial changes when social and physical values are ignored. Because of planning decisions, the city square of Taksim emerges as a fragment of a historical city that illustrates these problems and the danger of losing the characteristics of its historical past in which different planning tools are handled independently from each other in everyday life.

\section{TAKSIM SQUARE AS A MEMORY SPACE LOCATION}

Taksim Square, which has an important value in the urban identity of Istanbul and in the memory of the inhabitants, is among the most important public spaces of Istanbul along with its importance in many other aspects [5].

It is located at the intersection of İstiklal Street, Siraselviler Street, Gümüşsuyu Street, Cumhuriyet Street, and Tarlabaşı Boulevard in the Beyoğlu district. The Square is a transfer center for major transportation links, with a high concentration of pedestrian and vehicle traffic, and it houses urban service areas and other functions.

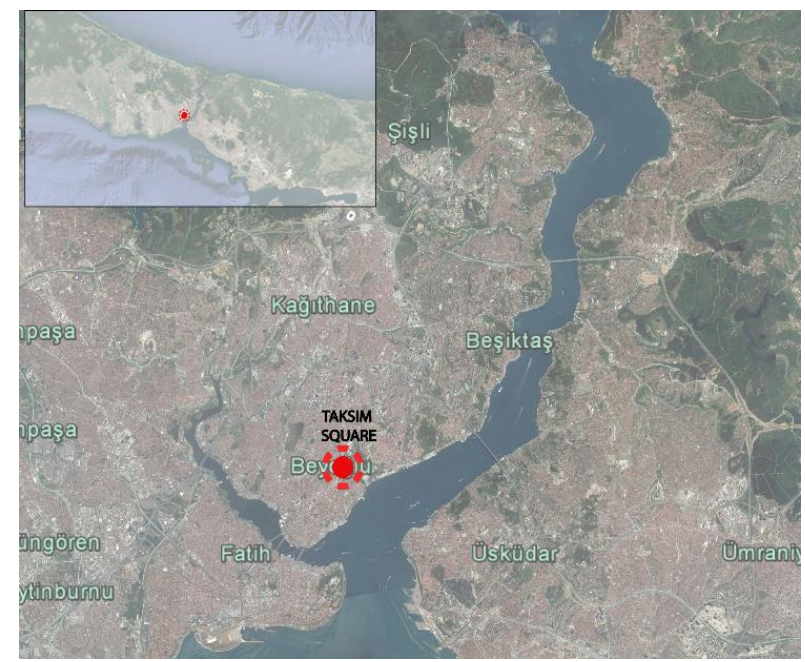

Fig. 1. Location of taksim square [6].

At the same time, Taksim Square is surrounded by Taksim Gezi Park, the Atatürk Cultural Center, The Marmara Hotel and a classical Ottoman style water Maksem (a historical water storage tank) that are important in the memory of the urban inhabitants.

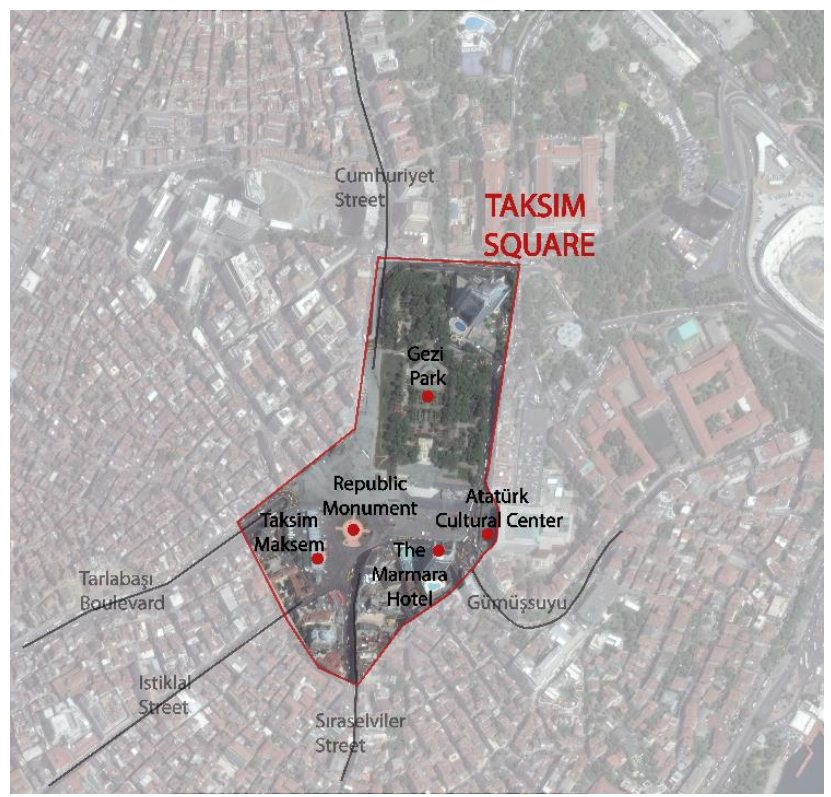

Fig. 2. Taksim square 


\section{HISTORY}

The examination of the formation and the processes of Taksim Square is quite important in terms of the understanding of its significance in the context of social memory in the historical process.

In the Republican period, it was seen that the first squares existed along with the provincial mansions and the provincial squares that were formed in front of these squares. Ceremonies took place here, and the people benefitted from the flow of political information that came from here. In this sense, squares and large streets are a state project in Turkey. The Square in the Taksim District was formed as a decision at the top with a series of political steps, not through the natural development of the area. In this respect, the changes in the historical process of Taksim Square have been examined since the Republican Era and have been focused on the changes that the square has experienced since the 1980s because part of the interventions made since 1980 have caused the area's memory to gradually disappear and have threatened the sustainability of the values it possesses.

Taksim Square got its name from Taksim Maksem, reached its ultimate condition in 1839, and was built to transfer the water coming to the European part toward the three parts of the city. This area was a narrow space where old houses were in existence before becoming an urban square [7]. Even though it is a monumental structure, its presence is not very clear today because it is at the corner of the square, and it has lost its function.

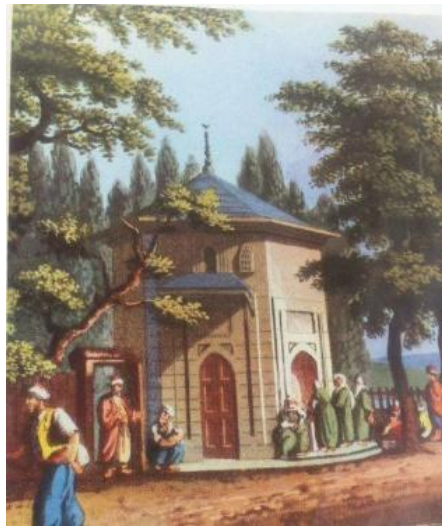

Fig. 3. Taksim maksem in the Ottoman period [7].

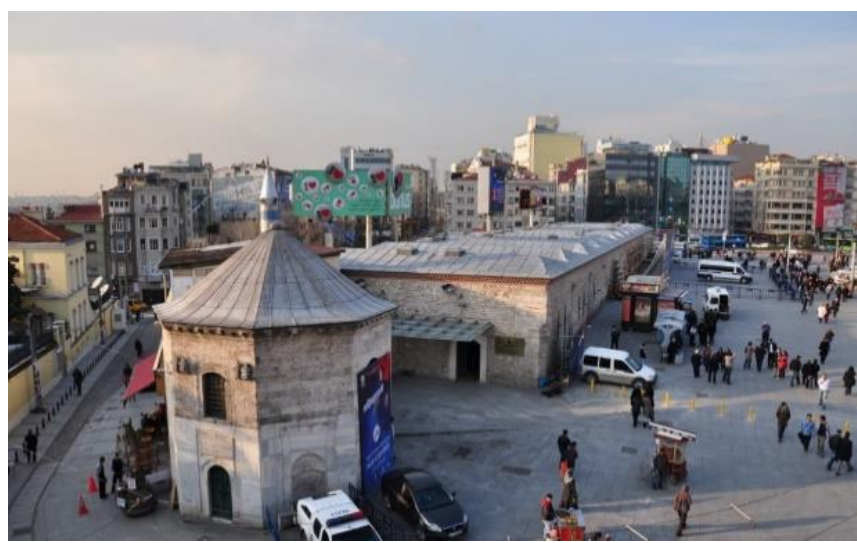

Fig. 4. Current view of taksim maksem [8].

In the context of the present study, the change in the historical process with this classification is examined under three periods:

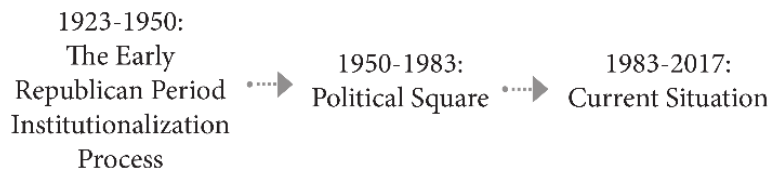

Fig. 5. Taksim square historical periods.

\section{Between 1923 and 1950: The Early Republican Period Institutionalization Process}

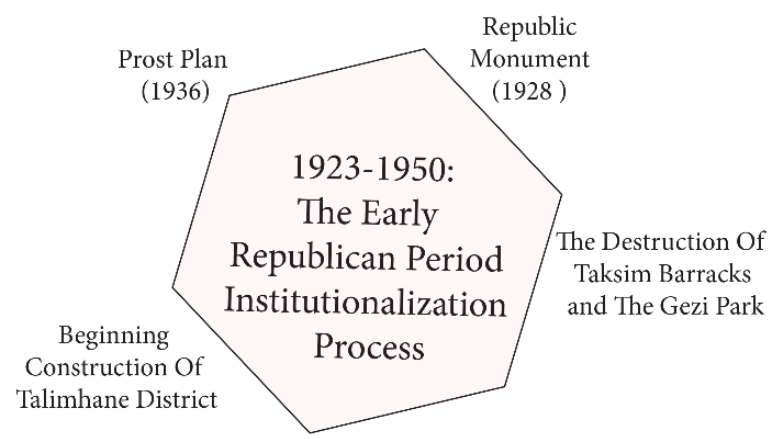

Fig. 6. The Period 1923-1950.

This period, the Early Republican Period, reached from declaration of the Republic of Turkey to the end of Second World War is an "establishment and institutionalization" period in terms of the national identity of Turkey. Among the most significant group of tools of this identity are the architectural and urban regulations.

In 1930s, the first thing to come to mind in Taksim is the monument that was erected in 1928. Taksim, a countryside plain until then, became a "city square" after this monument was built. The political and social side of this monument is as important as its urban meaning. The Taksim Monument is a symbol of a new era in Turkish history.

Until the Republican period, there was no square for a ceremony to be held in Istanbul. When the new era started with the Republic declaration, the first answer to this need was a Republican Monument, which was opened with a great ceremony on August 8, 1928. Until that day, such a crowd had not been seen in any field: thirty thousand people had gathered.

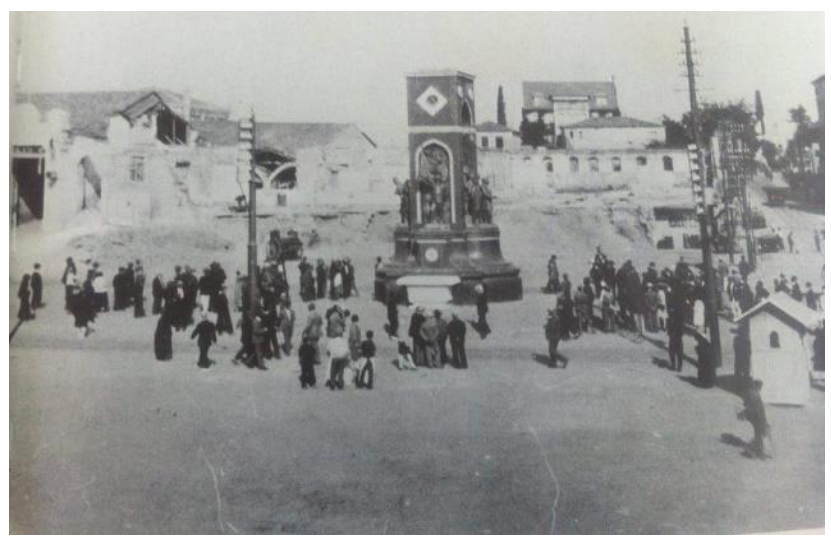

Fig.7. The new erected situation of taksim monument [7].

In the 1930s, the buildings of Taksim Artillery Barracks were evacuated, but the football field in the courtyard was maintained.

In 1940s, a huge reconstruction movement took place in Turkey, and the city most affected by that movement was 
İstanbul. Taksim and its surrounding were also modernized. Wrecked and ruined buildings were demolished to give the area a new identity, and streets leading to the square were expanded and paved. The state produces its own system dynamics such as law, traditions, religion, culture, economy, politics and so on. It is the power, that controls, propagation of the discourse which produces the dynamics of its own system [9].

Through Prost's Beyoğlu plan, prepared as a regional plan, the Taksim barracks were demolished, and the area was re-arranged to contain Gezi Park and a Hilton Hotel. This plan was aimed to allow the area to have a theater, conference halls, gathering halls, clubs, bus terminals, post office, and parking lots [10].

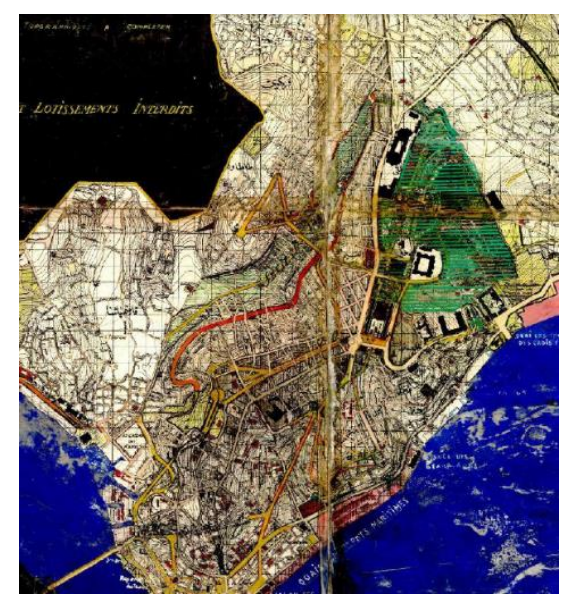

Fig. 8. Henri Prost plan dated 15/10/1937 - Beyoğlu Quarter [10].

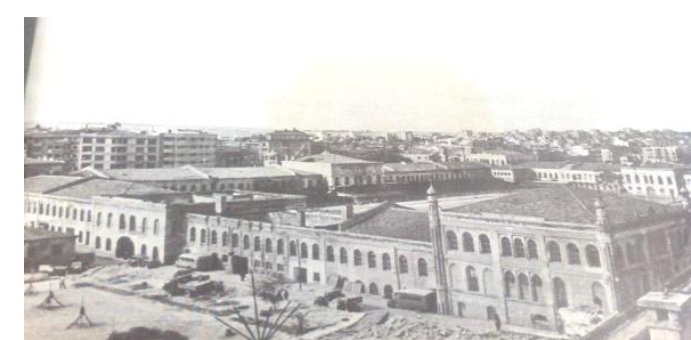

Fig. 9. Taksim Barracks before its demolition [7].

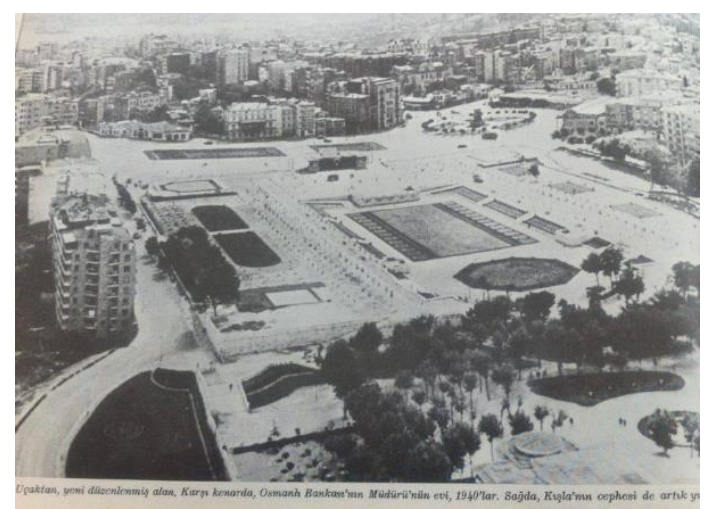

Fig. 10. Taksim barracks after its Demolition -Gezi Park [7].

The green area at Beyoğlu part, starting with the Taksim Walk, was named "Number 2 Park" by Prost. In 1937 the Master Plan, the Number 2 Park area was designated as the first area to be implemented through the plan put into practice shortly. The design of this park was elaborated in detail by Prost and the architects working in İstanbul Municipality. The design process for the park was developed along with the exchange of views and perspectives with municipal authorities and almost completed within a three-year period. The construction was completed in a short time and the opening of Gezi Park was pronounced by Mayor Dr. Lütfi Kırdar in 1943. Taksim Gezi Park has the characteristic of being a significant "cultural asset" along with its features of a public space: a ceremonial and monumental area, and a symbolic space as a representation of culture and urban understanding of early Republican period. It was an urban open space as a living and used component of the holistic structure that creates green system in urban scale and a distinctive open-space design representing its period among different park designs dedicated to different periods. As a historical and aesthetic space with great plane trees that had to be carefully protected and registered one by one, it had with an axial and at the same time an organic layout with the idea of creating an open perspective in accordance with this design concept. It served as a place of memory along with the adoption of the area in the collective memory of inhabitants as being the living space of different periods, and it was place contributing to the urban and environmental identity by determining the spatial identity of Taksim along with the integration with Taksim Square as one of the most significant squares of İstanbul [5].

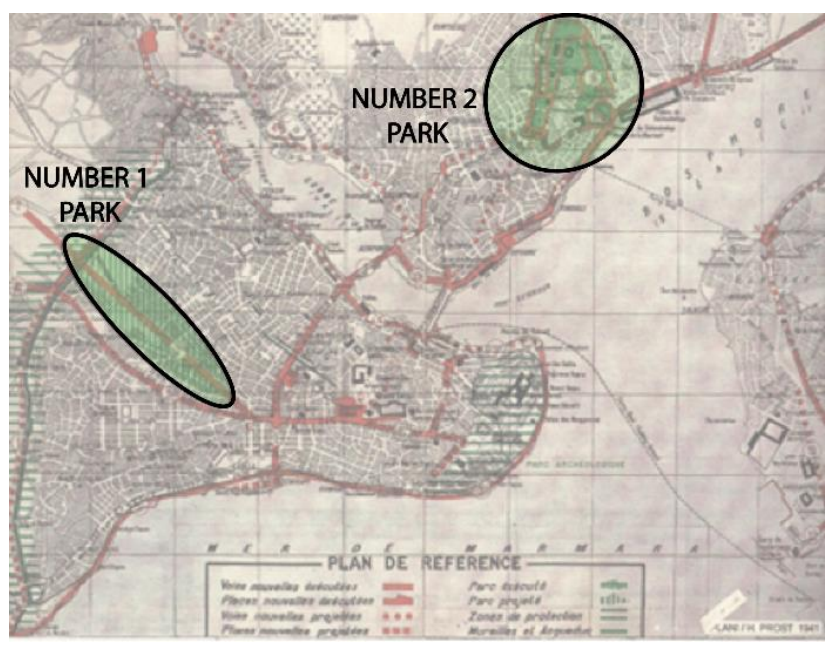

Fig. 11. İstanbul master plan prepared by prost - reference plan 1937 [5].

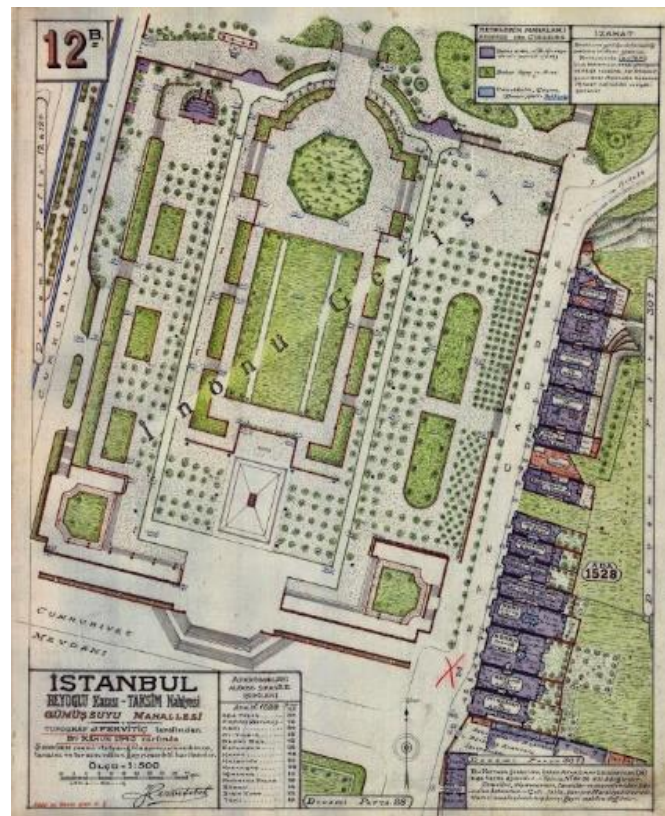

Fig. 12. The plan of taksim İnönü walk drawn by pervititch in 1943 [11]. 
After the demolition of the barracks, most of the area was joined to the square and some of it to the municipal garden. This area was the starting point for the urban green area that descended to Dolmabahçe. Subsequently, Taksim Square became more important and caused the neighborhoods to develop and to become Taksim Square as city center. Along with the demolition of large buildings, the area of the Square's enlarged and multifunctional quality, new construction such as a hotel and cultural palace began to be built.

The part of barracks used as the shooting area, today's "Talimhane", was constructed under the influence of Art Nouveau as the first planned example in Istanbul.

\section{Between 1950-1983: Political Square}

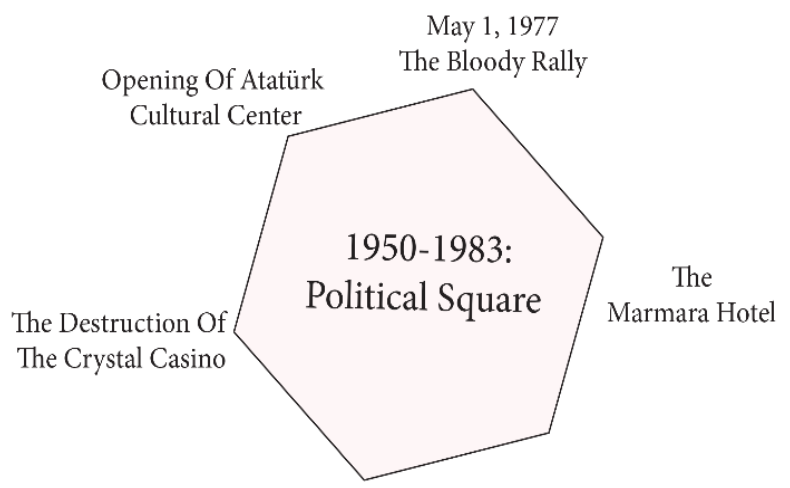

Fig. 13. Period 1950-1983.

The period between these years is remembered for Taksim Square as being mostly a political space. In particular, May 1 1977 is one of the most important incidents in social memory of Taksim Square: the May 1 Incident (1977) is associated with Taksim Square, and Taksim Square is also associated with May 1 Incident. Therefore, spaces that are strong in terms of social memory and worthy of "social memory" have a value and meaning beyond their own physical existence.

Demolition of the "Kristal Gazinosu" block at the beginning of 1970s, which existed in Talimhane at the beginning of Cunhuriyet Street, delivereda major blow to the integrity of the Square.

Taksim became an urban-scale square for ceremonies and demonstrations on national holidays and national or political events after the erection of Republic Monument. Because of the bloody end of the events that took place during the demonstrations of May 1, 1977, Taksim Square was closed to mass demonstrations, rallies, and walks after 1980.

In the first years of the period 1950 to 1983 , collectivism and institutionalization worked together. The Atatürk Culture Center, the City Opera, is the most significant example at square. In 1946, Governor and Mayor Dr. Lütfi Kırdar initiated the construction of the Atatürk Cultural Center in Taksim Square based on the projects of Architect Rükneddin Güney. The building under construction was transferred to the Ministry of Finance in 1953 due to financial difficulties and to the Ministry of Public Works in 1956. Hayati Tabanlıoğlu, who had earned a doctorate on theater studies in Germany, was tasked with examining the projects of this building and then with undertaking it as an architectural project advised by the German architect Prof. Gerhard Graubner. The project, which was proposed as an opera house with the name "Istanbul Opera", was qualified as a "cultural center" by the Hayati Tabanlıoğlu project. Both projects in succession were carried out by Hayati Tabanlıŏlu: the first was opened in 1969 as a "cultural palace", repaired after the fire in 1970 and reopened in 1977 as "Atatürk Cultural Center (ACC)" [12].

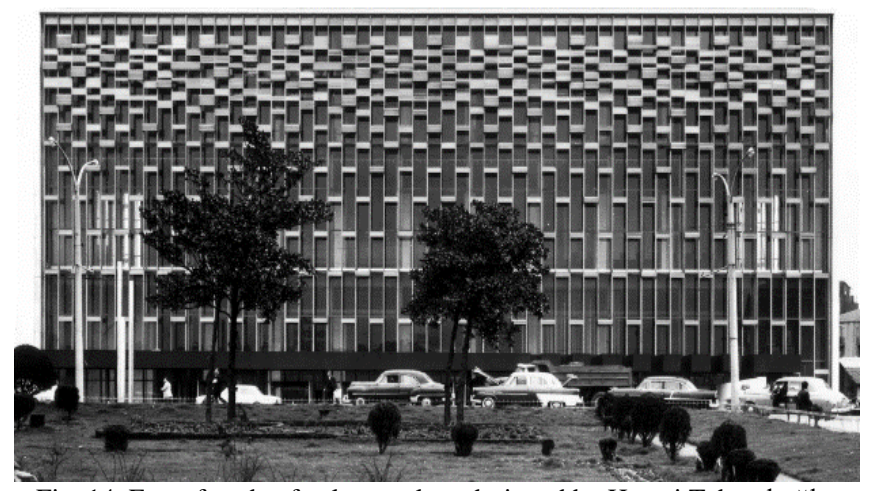

Fig. 14. Front façade of culture palace designed by Hayati Taban lıŏglu, dated 1969 [13].

Although the Atatürk Culture Center, which began operation in 1978, constitutes a strong boundary to the Square, adaptation of its modern facade it to a historical appearance has been controversial for a long time. Building heights of ACC and The Marmara Hotel were 4- to 5-times higher than the historical building height; thus, along with the buildings on the south and east sides of the Square, the Square has lost its historical monumental character in the historical sense due to vertical development.

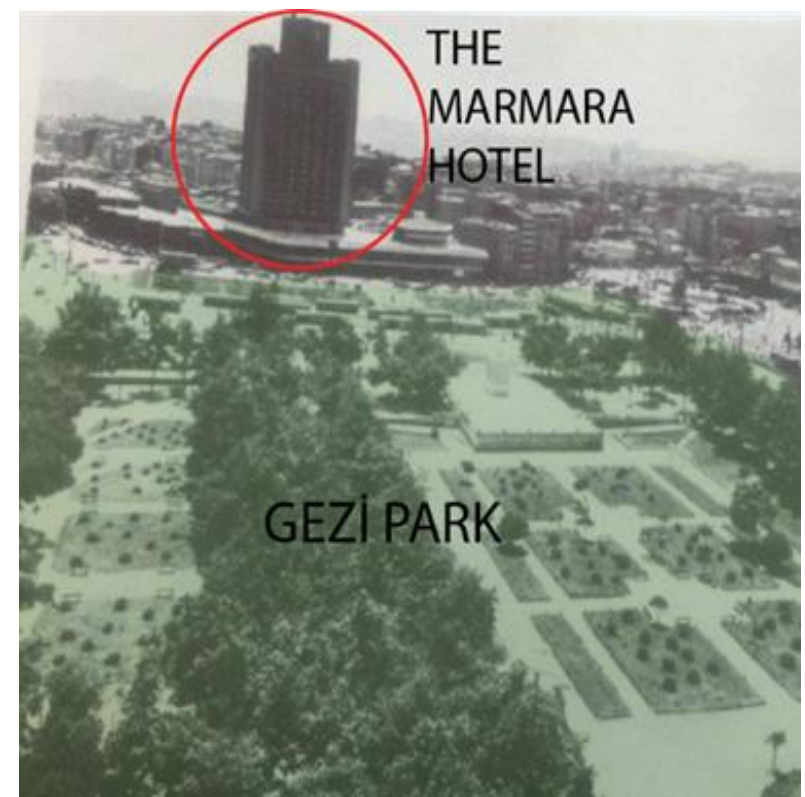

Fig. 15. The area after the construction of the Marmara hotel, 1980s [7]

In this period, a 1/5000 scale Beyoğlu Master Plan (1954), $1 / 1000$ scale $1^{\text {st }}$ Stage Plan of Beyoğlu (1972), and a 1/1000 scale Beyoğlu-Şişhane-Taksim $3^{\text {rd }}$ Stage Development Plan (1977) were approved. In 1972, Tarlabaşı Roads and crossroads planning, road extension, and expropriation decisions were the main decisions in the $1 / 1000$ scale Beyoğlu $1^{\text {st }}$ Stage Plan [14]. 


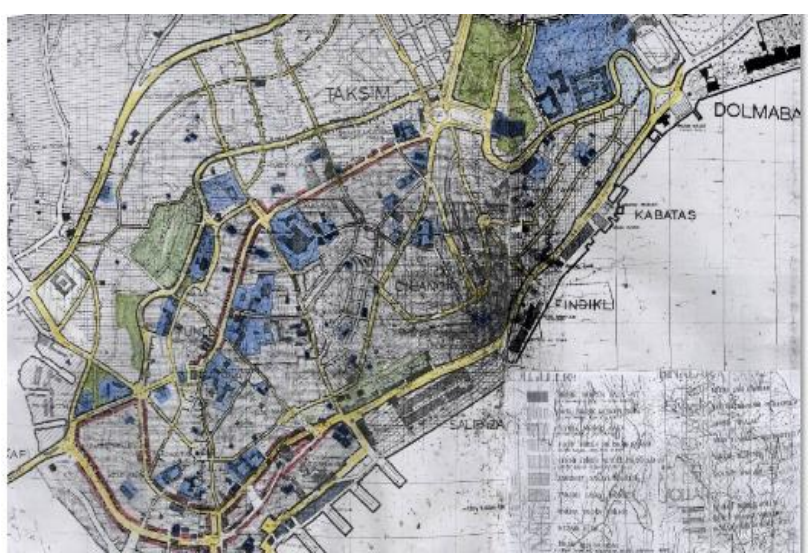

Fig. 16. 1/5000 scale Beyoğlu master plan with 17/02/1954 as the approval date [10].

In the $1 / 1000$ scale Beyoğlu-Şişhane-Taksim $3^{\text {rd }}$ Stage Development Plan in 1977, planning of the streets between İstiklal Street and Tophane, road extension decisions and designing commercial and residential uses together came into prominence as main decisions [15].

\section{Between 1983 - 2017: Current Situation}

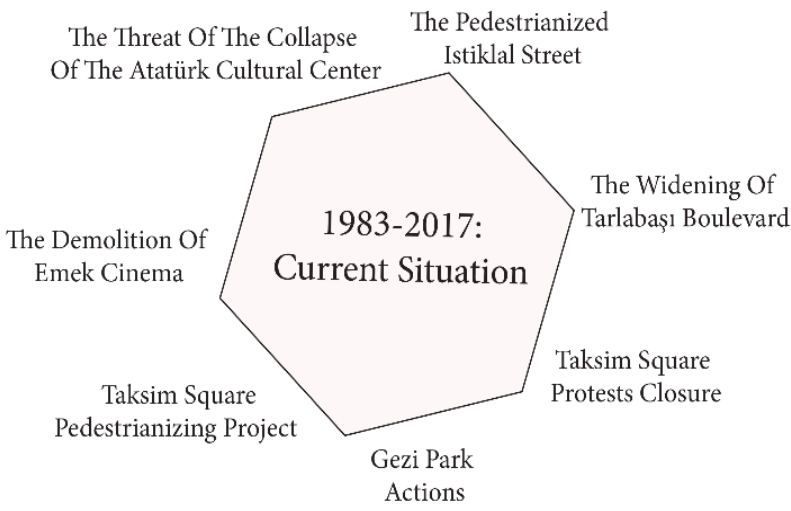

Fig. 17. Period between 1983-2017.

The neoliberal policies adopted by Turkey after 1980 and their spatial repercussions have also affected İstanbul and the old city center. Efforts to orient Istanbul to an internationalized marketplace begun to shape the spatial layout: a production-oriented structure, a financial sector, and tourism-oriented urban economy, combined tourism centers, business and shopping centers provided by the Tourism Incentive Law; foreign capital investments and the number of foreign-owned shopping centers and hypermarkets in the city has increased. Accordingly, in the 1980s, the Beyoğlu heritage was at the core of the controversy with the steps taken along with government support to make İstanbul a world city by global standards.

Because of the efforts to pedestrianize İstiklal Street and extension of Tarlabaşı Boulevard in 1986, the Republican Monument has a position as an undefined empty space.

In addition to cultural activities and art, many shops that were known for their wide shopping opportunities, producing, and marketing in İstiklal Caddesi simultaneously ceded their places to foreign capital, and the focus came to be on consumption only. However, thanks to the theaters, cinemas, art exhibitions, restaurants, cafes, and events that have been opened to service again, the Square has begun to regain its former vitality.

While transformation for tourism was being experienced at the surrounding of square, newly constructed buildings destroyed the urbanization process of inhabitants and formal memories of the city, and caused to it lose its special quality.

Beyoğlu and Taksim Square were again a topic of debate at the time that the "Wealth Party" won the İstanbul municipal election in 1994. At the beginning of the Refah Party era, which won the municipal elections in 1994 in opposition to Taksim's nationalist nation-state identity, debates began about bringing back the historical and cultural structure of Taksim and Beyoğlu. The construction of a mosque that will symbolize the nation-state and show the effect of Islam - instead of military ceremonies - and reveal the "true meaning" of the Istanbul conquest has begun to be discussed. This led to Taksim Square becoming the scene of identity wars.
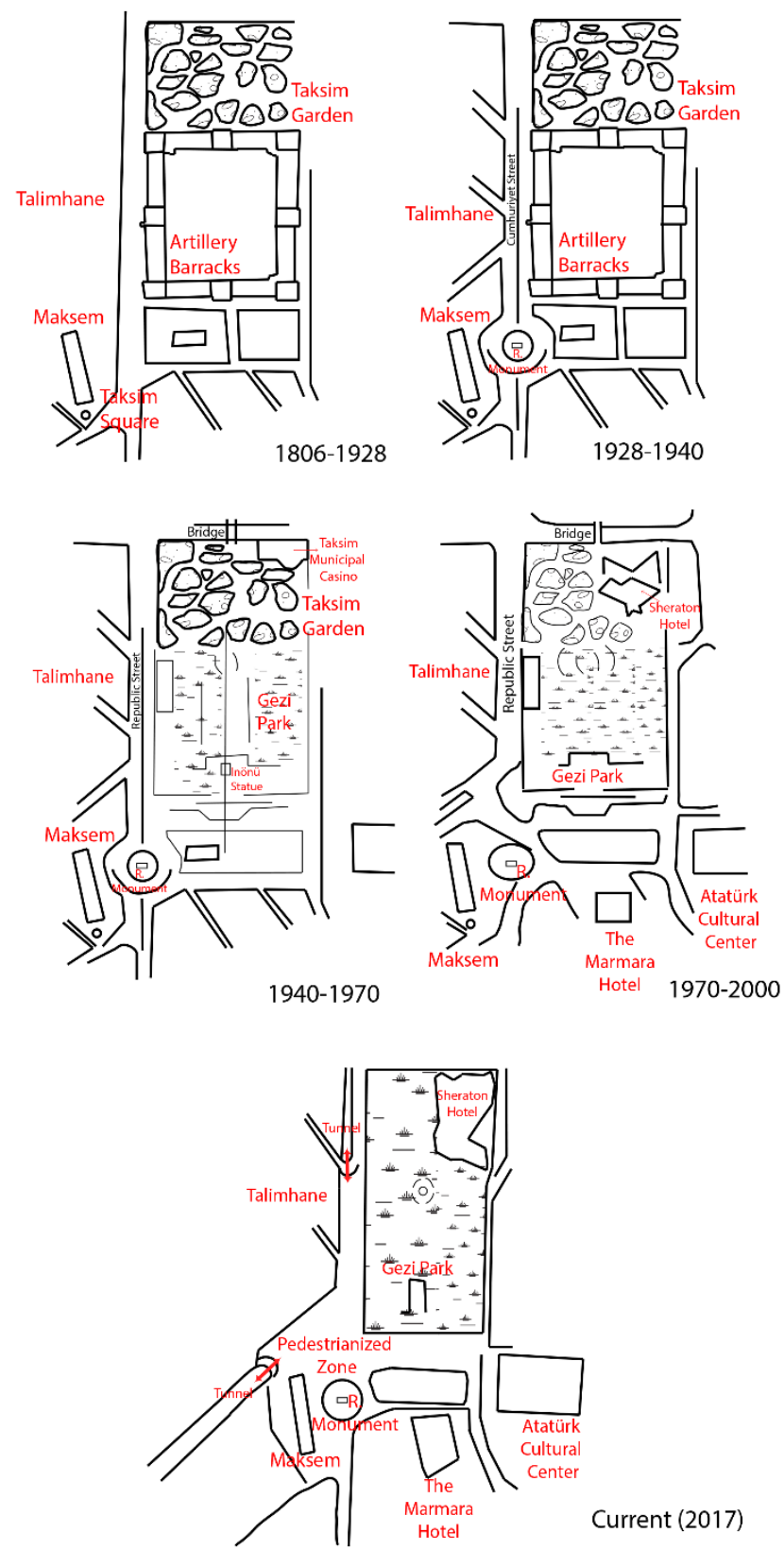

Fig. 18. A schematic representation of historical development of Taksim square.

In its own historical process, Taksim Square has become a 
place that has positioned it at the core of various projects. Taksim Square, home to much demolition and construction, is on the verge of a change. These changes have led to the gradual disappearance of the historical city memory that the Square has in the global world.

The demolition threat for Atatürk Culture Center (ACC) and demolition of Emek Cinema are implementations of government party policy in Taksim Square in recent years.

Since 2003, initiatives of the Minister of Culture and Tourism call for the destruction of ACC and the replacement of it with a "trade and congress center" as a giant structure. When the preparations for demolition faced widespread opposition, the discourse denying the identity of structure to justify the initiative began to be expressed through media. "Continuity" in terms of responding to the expectations of contemporary society for over 40 years from the date of its foundation, "memory" as a matter of debate along with social events, and "identity" as a physical part of the memory of İstanbul are among the important qualities of a structure. Furthermore, the Law of Conservation of Cultural and Natural Assets, law number 2863, and the fact that the district is a site area and the building registered as $1^{\text {st }}$ degree monumental structure provides the legal basis for conservation of the area. Despite these qualities and references, initiatives for the demolition of ACC were persistently pursued; for this purpose, extensive pressure has been applied on the board to remove the registration decision taken by the Conservation Board, which is regarded as an obstacle to the demolition. When the registration decision could not be removed, it was usedto carry out demolition through the Istanbul 2010 European Capital of Culture (ECC) Act. A static report was requested from Sakarya University with an expectation that the construction should be "demolished"; it was clearly understood that there was no architectural, technical, and legal basis for the demolition of the building in consequence of a university report mentioning that "the structure should be strengthened." However, the "ideological" discourse continued.

In recent years there has been constant pressure to demolish ACC. Although these pressures bring objections from society and cause prolongation of the process, different ways have been tried to apply the projects and demolish the ACC. Threats to demolish the structure remain.

This monumental building that exists on the place where social events have occurred, has been waiting for restoration today and is closed to audiences.

The 1/5000 scale Beyoğlu Urban Site Area Conservation Development Plan was approved on 21.05.2009 along with the number 2302 decision of İstanbul Number II, of the Regional Committee for the Protection of Cultural and Natural Assets dated 07.01.2009 [10].

In 2010, the 1/1000 scale Beyoğlu Urban Site Area Conservation Development Plan was approved. Its aim is to eliminate existing negativities; consider unique identity structures of the Historical Peninsula along with İstanbul and its regional historical, cultural, science, art, trade and tourism; put forward their distinctiveness through preserving them. protect historical, cultural, and architectural values; and reveal the attributes of continuity between the past and the future [10].

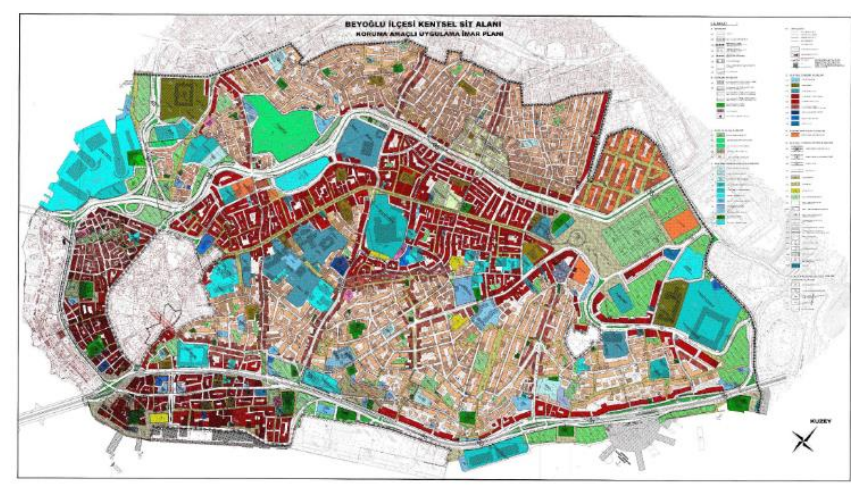

Fig. 19. Beyoğlu district urban site area 1/1000 scale conservation development plan [10].

In the plan, several goals are targeted, such as emphasizing the characteristics of districts with historical artifacts; intensifying and preserving and supporting them within the framework of their own functions; continuing participation of the lost monumental artifacts identified with historical and cultural identity of the district, as well as important examples of civil architecture [15].

In 2011, the project related to Taksim Square Re-arrangement was announced and was introduced to the public by the Prime Minister as at that time one of the prestigious projects for Istanbul. In the explanatory report of 1/1000 scale Beyoğlu Urban Site Area Conservation Development Plan, it is stated that the Tarlabaşı Boulevard traffic should be removed from Taksim Square; that the pedestrian circulation of İstiklal Caddesi should be integrated with the pedestrian demands of Taksim Square; and that the perception of the form of the Taksim Square and the surrounding structures should be increased [15].

Implementing the "Taksim Square Pedestrianizing Project" will lead to a fundamental change in Taksim Square, which was one of the first planned areas of Republican history of Turkey. It is aimed to be re-arranged along with the approval of "Beyoğlu District $1 / 5000$ and $1 / 1000$ scale Plan Renovations of Conservation Development Plan of Taksim Square Pedestrianization Project" by the number 2111 decision made by the İstanbul Metropolitan Municipality Assembly on 16 September 2011 [14].

The "Beyoğlu District 1/5000 and 1/1000 Scale Plan Renovations of Conservation Development Plan of Taksim Square Pedestrianization Project" was adopted unanimously by the İstanbul Metropolitan Municipality Assembly, and it approved that all existing traffic will be taken underground of the square along with the 04.12.2012-165 dated and numbered decision of number II Regional Committee for the Conservation of Cultural Assets. Furthermore, it is mentioned in the approved plan notes that Taksim Barracks, which was registered by decision number 4225 of the İstanbul Number II, The Regional Committee for the Conservation of Cultural Assets dated 09.02.2011 will be approached in integration with the urban design project. Further, it was noted that implementation within the boundary of plan approval will be carried out in the direction with the urban design project that is to be approved by committee. Along with such an application, a large part of the Gezi Park, a complementary element of this large green system linking Taksim Square to the Number 2 Park, which 
was obtained through city planning process, will be removed and a conservation problem will be created. The fact that Taksim Gezi Park, which is a cultural asset built in the framework of Prost along with the integrity of free spaces as an exact subject of conservation, will have been destroyed along with the desire to make the structure, which was demolished and not in existence today, as the subject of conservation [5].

The project and its process related to taking the vehicular traffic underground by means of pedestrianizing Taksim and removing Gezi Park and replacing it with the new Artillery Barracks building as shopping mall, which was demolished in 1939, remained on the agenda along with the discussions at various levels in 2012. In other words, after Gezi Park, which was created after the demolition of Artillery Barracks, accumulated its own historicity, it faced the threat of demolition to open the way for the re-construction of a barracks. This project, not the result of a real demand, started to be implemented at the end of 2012 without producing a formula that would reconcile the public authority with social expectations [14].

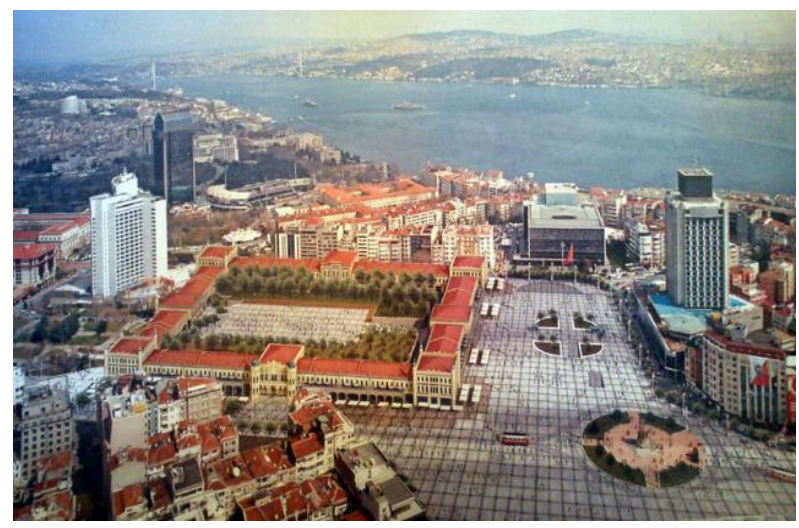

Fig. 20. Taksim barracks revitalization project [16].

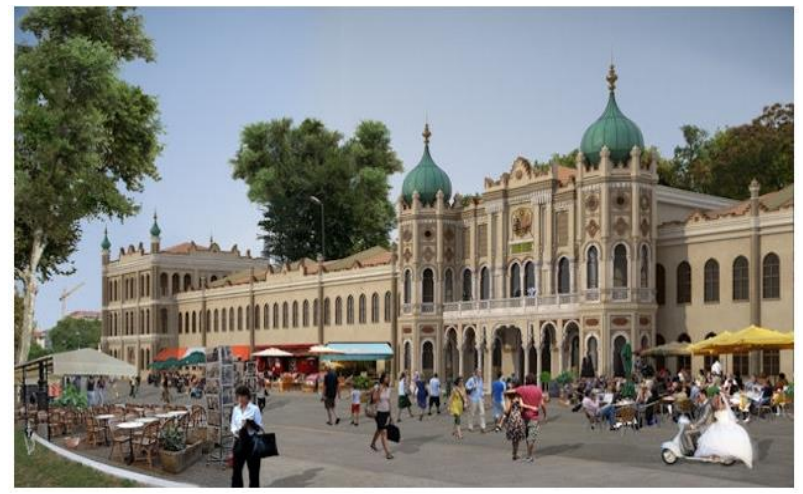

Fig. 21. Taksim barracks revitalization project [17].

This project, belonging to the Istanbul Metropolitan Municipality, envisaged cutting some trees in the Gezi Park. This led to the start of Taksim Gezi Park Resistance, which started as a demonstration to prevent new Artillery Barracks Project, which had been designed for Taksim Gezi Park in the Beyoğlu District despite the decisions of İstanbul $6^{\text {th }}$ Administrative Court and Number 2 Conservation Committee for Cultural and Natural Assets. The resistance that started on May 27, 2013 following the entry of the caterpillars into Gezi Park soon turned into a massive demonstration.

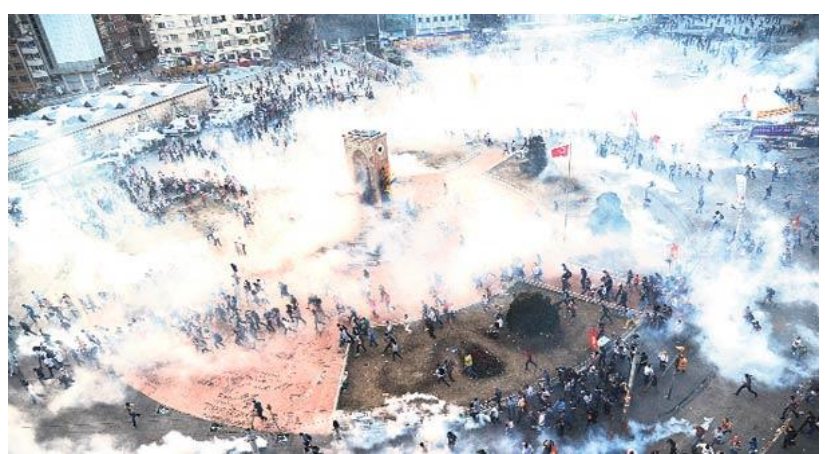

Fig. 22. Gezi park resistance [18].

The Chamber of City Planners, the Chamber of Architects and the Chamber of Landscape Architects filed suit to 1/5000 and 1/1000 scale Plan Renovations of Conservation Development Plan of Taksim Square Pedestrianization Project" by the decision number 2111 taken by the İstanbul Metropolitan Municipality Assembly 16 September 2011; the court canceled the project on 06.06.2013. A commission of experts composed of three people mentioned that plan renovations were contrary to the principles of urbanism, planning and conservation [14]. Although the court cancelled the entire project, the tunnel part of Taksim Pedestrianizing project was implemented in September 2013. The Taksim Tarlabaşı Boulevard and Cumhuriyet Street traffic were taken underground. The traffic at Taksim Square and İstiklal Street Entrances have been completely removed.
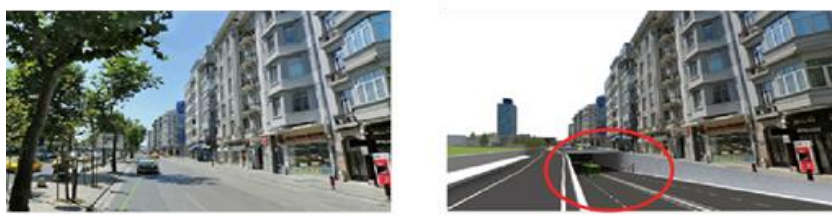

Fig. 23. Cumhuriyet Street before and after [19].

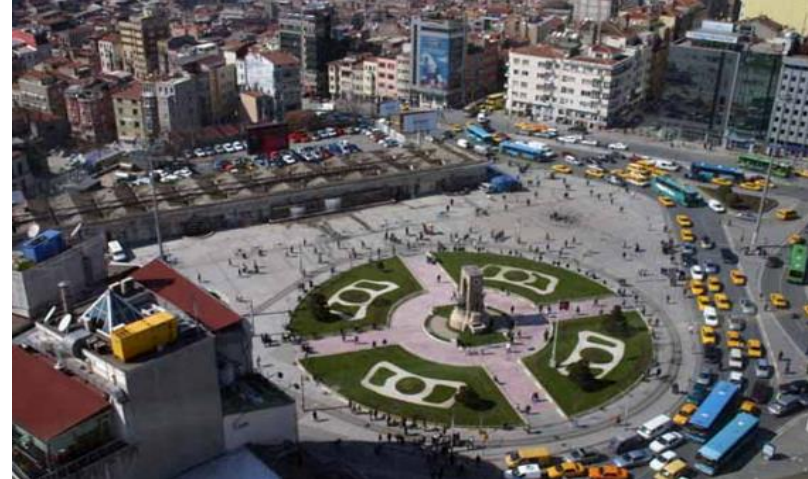

Fig. 24. Taksim Square before pedestrianizaing project [20].

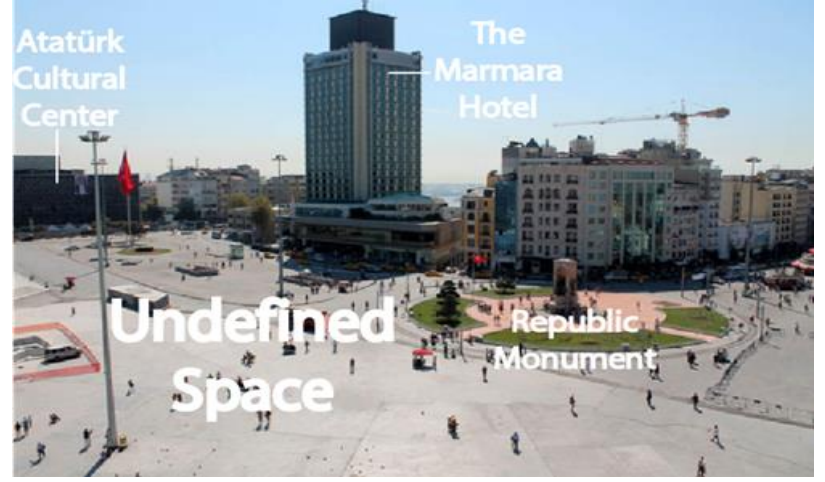

Fig. 25. Undefined space that emerged after the Taksim Square Pedestrianizing Project [19]. 


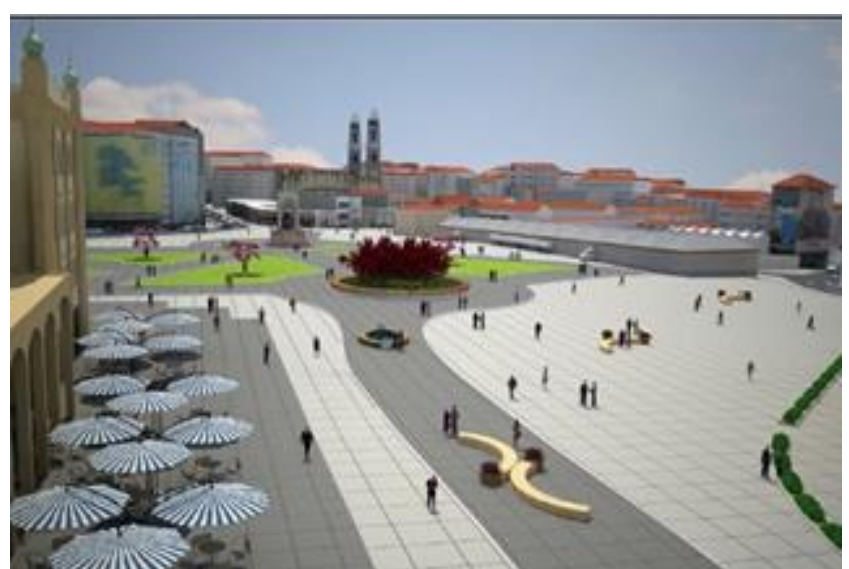

Fig. 26. Taksim square pedestrianizing project, cumhuriyet square pedestrianized area [20].

In this project, vehicles on Taksim Square are seen as the biggest problem. For years, the transportation facilities that the pedestrians and the vehicles had merged together entered the city maps and worked on the urban memory. It is an important dynamic that determines the identity of a place where pedestrians and vehicles coexist on the streets that feed the square. In the past, pedestrians and vehicles have lived together without any problem in squares. The project, which aimed to take the vehicle traffic to underground and saw it as an important problem in the square, will remove the space identity of the Square. The project, which started with the pedestrianizing approach, can transform the area into a void again. The proposed project is a concrete plateau measuring 98,000 square meters. What matters is not the size of a square, but the design of living space on a human scale. This project will ignore the structural scale of the Republic Monument. As mentioned, obviously in Conservation Committee decisions, it is the fact that any structure that is planned to be built on the place where Gezi Park exists near Taksim Makse, creates a sense of untouchableness for Taksim Square, the Atatürk Culture Center, and other registered cultural assets; it will irreversibly harm the identity of this historical square.

The historical landscape of the area deteriorated, along with the fact that underground tunnels within the project caused the separation of the relationship between the existing road, building, and pedestrians. In addition, the May 1 celebrations, allowed in Taksim in 2010 and 2011, were banned due to the pedestrianizing project in the Square. Closing of the Square to social demonstrations causes the disappearance of a social aspect of urban memory. The identity of the gathering as a meeting place in the social memory of Taksim Square will change along with the project.

\section{CONCLUSION: AN APPROACH TO MEMORY OF TAKSIM SQUARE FROM THE PERSPECTIVE OF HISTORICAL URBAN LANDSCAPE}

According to the Historical Urban Landscape Recommendation Decision adopted by UNESCO in 2011, in consideration of the dynamic structures of the living cities includes the ways to make possible the realization of urban conservation and sustainable development, as well as to assign significance to the historical layers of the cities, existing cultural diversity, and natural structures. According to the $8^{\text {th }}$ title of the Historical Urban Landscape Recommendation Decision in its definitions section, this approach strengthens production and sustainable use of urban spaces along with preserving the environmental quality of life for individuals, and supports social and functional diversity by considering dynamic structures of cities. In addition, this approach, which integrates urban conservation and economic development goals, considers the urban and the natural environment as well; it depends on a balanced and sustainable relationship between the needs of current and future generations. The Historical Urban Landscape (HUL) approach reflects the fact that disciplines and practices for preserving urban heritage have developed more and more over the last few decades, enabling policy makers and managers to effectively respond to new challenges and opportunities. The HUL approach supports the pursuit of the development and adaptation of societies; their history, their collective memories and the maintenance of the attributes and values related to their environment.

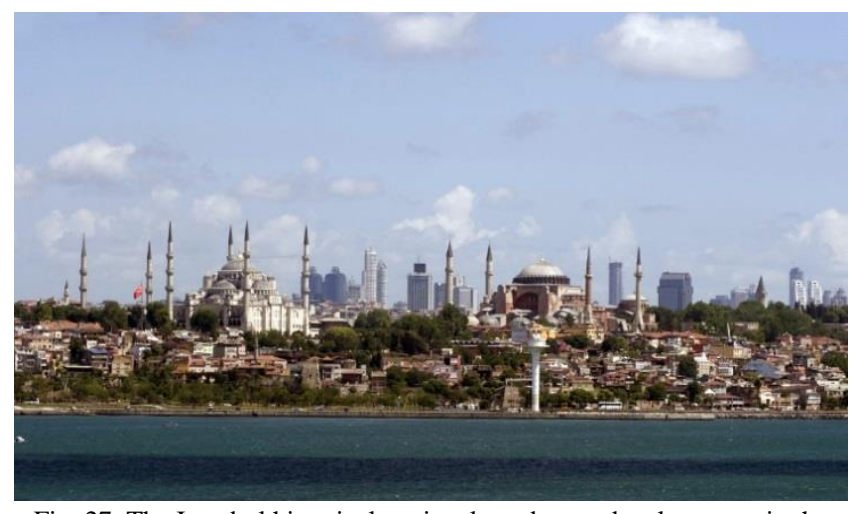

Fig. 27. The Istanbul historical peninsula and $\mathrm{n}$ ew developments in the background.

TABLE 1: DETERMINANT SPACES IN TAKSIM SQUARE AND LOSS OF

\begin{tabular}{|l|l|l|l|}
\hline \multicolumn{1}{|c|}{ MEMORY } \\
\begin{tabular}{|l} 
Functions/Structures/ \\
Values
\end{tabular} & $\begin{array}{l}\text { Existence } \\
\text { from Past } \\
\text { to } \\
\text { Present }\end{array}$ & $\begin{array}{l}\text { Under the } \\
\text { Threat of } \\
\text { Being Lost } \\
\text { Today }\end{array}$ & $\begin{array}{l}\text { No } \\
\text { Existence } \\
\text { and } \\
\text { Functioning } \\
\text { Today }\end{array}$ \\
\hline $\begin{array}{l}\text { Atatürk Cultural } \\
\text { Center }\end{array}$ & & X & \\
\hline Gezi Park & & $\mathrm{X}$ & \\
\hline Taksim Maksem & & $\mathrm{X}$ & \\
\hline $\begin{array}{l}\text { Emek Cinema } \\
\text { İstiklal Street }\end{array}$ & & $\mathrm{X}$ & \\
\hline Republic Monument & & & $\mathrm{X}$ \\
\hline The Marmara Hotel & & $\mathrm{X}$ & \\
\hline $\begin{array}{l}\text { Characteristic of } \\
\text { Place }\end{array}$ & & & \\
\hline
\end{tabular}

As follows from the Table, in Taksim Square a large part of the memory-defining space is faced with the threat of extinction by current projects and plan decisions. Every intervention to be made in a historical square of a metropolitan city will affect the memory of urban inhabitants. Urban dynamics and urban conservation approaches are often 
contradictory, but HUL principles suggest that a balanced and sustainable relationship can be built that will remove these contradictions between historical heritage sites and the needs of present and future generations. At the core of this concept, participatory and transparent decision-making processes as well as concrete cultural heritage and the significance put on urban memory do exist.

The Historical Urban Landscape Recommendation Decision defines the means in this regard. The HUL-based approach involves the application of traditional and innovative tools to local environments. Some of these tools, which need to be developed as part of a process involving different participants, can include:

Civil participatory means, which should include different and interconnected participants, identify key values in their urban areas to protect their heritage, and promote sustainable development, develop their vision of diversity, be empowered to make joint decisions in goal setting and action. These instruments, constituting an integral part of urban administration dynamics, should develop an intercultural dialogue along with finding information about history, tradition, values, and needs of different societies as well as negotiating and mediating conflicting interests and groups.

Knowledge and planning means, which should help to ensure integrity and authenticity consistent with the characteristics of urban heritage. At the same time, it should allow recognition of cultural heritage and diversity, and should also enable the oversight and management of change to improve the quality of life in urban areas.

Regulatory systems, which should reflect local conditions and include legislative measures and supervisory precautions on tangible and non-tangible characteristics of urban heritage, including social, environmental, and cultural values. Traditional and conventional systems should be recognized and strengthened accordingly.

Financial means, which should aim at capacity building and support the development of innovative income generation that has roots in tradition. In addition to the global funds provided by governments and international organizations, financial instruments should contribute to the effective use of micro-level private investments. Micro-credit and other flexible financing methods that support local initiatives, as well as partnerships, have a major significance.

\section{REFERENCES}

[1] F. Bandarin and R. van Oers, The Historic Urban Landscape; Managing Heritage in An Urban Century, Oxford: Wiley \& Blackwell Publishing, 2012.

[2] Z. Ahunbay, Tarihi Çevre Koruma ve Restorasyon, Istanbul: YEM Publications, 1996.

[3] World Heritage, UNESCO, 15th General Assembly of States Parties, WHC-05/15.GA/7, October 2005 .

[4] UNESCO World Heritage Committee, WHC.07/31.COM/7B, Paris, 2007.

[5] G. Özaydın. (2012). Taksim'in Üstü altina iniyor. Mimarlık Dergisi. [Online]. Available: http://www.mimarlikdergisi.com/index.cfm

[6] Google Earth, July 2016.

[7] Ç. Gülersoy, Taksim: Bir Meydanın Hikayesi, İstanbul Kitaplığı: İstanbul, p. 84, 1986.

[8] URL-1. [Online]. Available: http://vivahiba.com/article/show/bir-meydanin-hikayesi-taksim/ 12.6.2017
[9] M. Ozkan Ozbek, "Sinırda olanlar, marjinaller ve mekansal İzdüşümleri,” Mimar-ist, pp. 85-89, 2017.

[10] Spatial Planning: Beyoğlu Presentation, Beyoğlu Municipality, Urban Planning Department, 2014.

[11] URL-2. [Online]. Available: http://www.istanbulium.net/2014/07/pervititch-haritalar-kadikoy-usku dar.html

[12] M. Tabanlığlu. (2010). İstanbul AKM yenilenirken. Mimarlık Dergisi. [Online]. $352 . \quad$ Available: http://www.mimarlikdergisi.com/index.cfm?sayfa=mimarlik\&DergiS ayi $=366 \& \operatorname{Rec} I D=2319$

[13] URL-3. Modernin İcrası: Atatürk Kültür Merkezi 1946-1977 $\begin{array}{lll}\text { Exhibition. } & \text { [Online]. Available: }\end{array}$ https://www.google.com/culturalinstitute/beta/exhibit/modern\%C4\% B0n-\%C4\%B0crasi-atat\%C3\%9Crk-k\%C3\%9Clt\%C3\%9Cr-merkez $\% \mathrm{C} 4 \% \mathrm{~B} 0 / \mathrm{QQkLdz} 58$ ?hl=tr

[14] S. Gelen, "Tarihi Kent Merkezlerinin Kamusal Gücünün Kentsel Tasarım Bağlamında Değerlendirilmesi: İstiklal Caddesi Aksı Ve Taksim Meydanı (İstanbul) Örneği," MSc dissertation, Dokuz Eylül University: İzmir, 2016.

[15] İ. Öztemiz, "Koruma Amaçli İmar Planlarinin Kentsel Tasarim Ölçütlerine Göre Değerlendirilmesi: Beyoğlu Koruma Amaçli Nazim İmar Planı Örneği," MSc dissertation, Mimar Sinan Fine Arts University: İstanbul, 2012.

[16] URL-4. [Online]. Available: http://www.diken.com.tr/topbastan-mujde-topcu-kislasi-da-kabatas-m eydan-projesi-de-yapilacak/

[17] URL-5. [Online]. Available: http://www.arkitera.com/gorus/268/hayal-et-yapilar-sergisi-nde-taksi m-kislasi

[18] URL-6.

[Online].

Available: http://www.sozcu.com.tr/2014/dunya/otpor-lideri-gezi-eylemleriyle-il gili-konustu-664077/

[19] URL-8. [Online]. Available: http://www.kanalistanbul.com.tr/taksim-meydani-yayalastirma-projesi -son-durum

[20] URL-9. [Online]. Available: https://ibbqr.ibb.gov.tr/taksim-meydani-cevre-duzenleme-insaati/

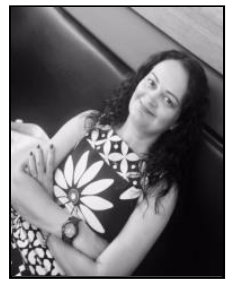

Dilek Erbey was born in Ankara, in 1970. She has BSc Urban and Regional Planning, MSc on Urban Conservation Planning; Dissertation: "Social and Economic Changes and Effects on Historical Centres, Balat- Istanbul Case and the Phd on Urban and Regional Planning; Dissertation: "Urban Regeneration Projects as A Tool for Urban Conservation" in Mimar Sinan Fine Arts University, Istanbul, Turkey. She studied and joined various educational programmes in Roma La Sapienza University, Italy, Lisbon Technical University, Portugal and ICCROM (International Centre for Conservation and Restoration of Monuments) on heritage and urban conservation issues.

She has been working as a lecture since 1992 in the Faculty of Architecture, Department of City and Regional Planning, Mimar Sinan Fine Arts University, Istanbul. She is giving courses on urban conservation, renewal, urban regeneration and heritage management for undergraduate and graguate levels. She has several articles. International Journal of Sustainable Development and Planning, "The Challenges on Spatial Continuity of Urban Regeneration Projects: The Case of Fener Balat Historical District in Istanbul", Ed. C.A. Brebbia, A. Galiano-Garrigos, WIT Press, 2017. Journal of Urban Studies, An Evaluation of the Applicability of Management Plans with Public Participation, Ed. M. Altunoğlu, Z. Çelik, Ş. Geniş, O. İmga, Ankara, 2016. Her research interests are on on the topics urban conservation, heritage management and urban regeneration.

Asst. Prof. Dr. Erbey is a member of Advisory Board of Site Management Plan of "Istanbul World Heritage Sites" since 2010, of Europa Nostra Turkey, Chamber of Urban Planners of Turkey and a team member of Aphrodisias Antic City Site Management Plan. 